\title{
PERLINDUNGAN HUKUM TERHADAP PENGGUNA JASA PENGIRIMAN BARANG DENGAN KENDARAAN BERMOTOR UMUM PADA PT. PAHALA EXPRESS DELIVERY DENPASAR ${ }^{*}$
}

\author{
Oleh: \\ Ida Bagus Ketut Agastya** \\ I Made Udiana*** \\ Anak Agung Ketut Sukranatha*** \\ Program Kekhususan Hukum Bisnis, Fakultas Hukum Universitas \\ Udayana
}

\begin{abstract}
ABSTRAK
Pengangkutan merupakan suatu sarana yang sangat penting untuk melancarkan kegiatan perekonomian masyarakat, salah satunya yaitu angkutan barang. PT. Pahala Express Delivery memberikan layanan jasa pengiriman barang yang dapat memudahkan masyarakat untuk mengirim barang. Pengangkut wajib mengangkut barang dengan aman dan selamat sampai tiba pada tujuan. Berdasarkan latar belakang tersebut, adapun permasalahan dan tujuan penelitian ini yaitu bagaimana tindakan preventif PT. Pahala Express Delivery Denpasar untuk menghindari terjadinya kerugian terhadap pengguna jasa serta tanggung jawab PT. Pahala Express Delivery Denpasar terhadap kerugian yang diderita oleh pengguna jasa. Metode penelitian dalam penelitian ini menggunakan penelitian hukum empiris.

Berdasarkan hasil penelitian bahwa PT. Pahala Express Delivery Denpasar memberikan tindakan preventif mencegah kerugian pengguna jasa dengan memeriksa dan meminta keterangan barang, mengasuransikan barang mahal, menyarankan dibungkus kayu, plastik gelembung dan karung, mencatat keterangan barang, memberikan nomor resi sebagai nota/ bukti pembayaran. Tanggung jawab terhadap kerugian pengguna jasa belum sepenuhnya sesuai dengan peraturan perundang-undangan karena ganti rugi yang diberikan kepada pengguna jasa yang mengalami kerusakan atau kehilangan barang untuk yang tidak diasuransikan tidak dapat ditanggung secara penuh apabila melebihi sepuluh kali biaya pengiriman dengan jumlah maksimal

* Tulisan ini merupakan ringkasan skripsi.

** Ida Bagus Ketut Agastya adalah Mahasiswa Fakultas Hukum Universitas Udayana, Email: gusagastya@gmail.com.

*** Dr. I Made Udiana, SH.,MH adalah Dosen Fakultas Hukum Universitas Udayana, Email: udianabali@gmail.com.

**** Anak Agung Ketut Sukranatha, SH.,MH adalah Dosen Fakultas Hukum Universitas Udayana, Email: agung_sukranatha@unud.ac.id.
\end{abstract}


tidak melebihi Rp.750.000, sedangkan yang diasuransikan ditanggung oleh jasa asuransi sesuai yang dialami. Mengenai keterlambatan layanan Express tidak diberikan ganti rugi keterlambatan.

\title{
Kata Kunci: Perlindungan Hukum, Pengguna Jasa, Jasa Pengiriman Barang
}

\begin{abstract}
Transportation is a very important tool for launching community economic activities, one of which is freight transportation. PT. Pahala Express Delivery provide freight forwarding services that can make it easier for people to send goods. The carrier must transport the goods safely and secure until they arrive at their destination. Based on this background, as for the problems and the research purpose is how preventive actions of PT. Pahala Express Delivery Denpasar to avoid losses to service users and the responsibility of PT. Pahala Express Delivery Denpasar for losses suffered by service users. The research method in this study uses empirical legal research.

Based on the results of research that PT. Pahala Express Delivery Denpasar provides preventive measures to prevent loss of service users by checking and requesting information on goods, insure expensive goods, suggest for wood wrapped, bubble plastic and sacks, record goods information, providing receipt numbers as proof of payment. The responsibility for loss of service users is not fully accordance with the laws because, compensation given to service users who experience damage or loss of goods for uninsured can not be borne in full if it exceeds ten times shipping costs with a maximum amount not exceeding Rp.750,000, while the insured is borne by insurance services according to those experienced. Regarding the delay of the Express service is not given a late compensation.
\end{abstract}

\section{Keywords: Legal Protection, Service User, Delivery Service}

\section{PENDAHULUAN}

\subsection{Latar Belakang}

Pengangkutan bertambah maju dapat memudahkan manusia dalam berbagai kegiatan. Fungsi pengangkutan ialah untuk meningkatkan daya guna dan nilai. ${ }^{1}$ Pengangkutan juga merupakan

${ }^{1}$ H.M.N. Purwosutjipto, 2003, Pengertian Pokok Hukum Dagang Indonesia III Hukum Pengangkutan, Djambatan, Jakarta, h. 1. 
penghubung antara penjual dengan pembeli dalam menyampaikan barang. Untuk mempermudah melakukan kegiatan ini diperlukan peraturan-peraturan yang mengatur ketertiban, keamaan, dan keselamatan melaksankan angkutan.

Kemajuan dalam bidang angkutan ini menimbulkan banyak perusahaan jasa pengiriman barang yang sering dimanfaatkan oleh masyarakat maupun penjual yang menjual produknya melaui internet (online). Dengan adanya jasa pengiriman barang, berbelanja secara online atau mengirim barang sangat mudah dilakukan tanpa harus membawa sendiri barangnya melainkan dapat menggunakan jasa pengiriman barang. Hal ini sangat diminati oleh masyarakat karena lebih praktis serta di pandang lebih aman karena selama proses pengiriman, barang yang dikirim telah menjadi tanggung jawab perusahaan jasa pengiriman barang dimulai dari barang diterima sampai barang tiba ditujuan.

Di Indonesia sekarang terdapat perusahaan pengiriman barang baik milik pemerintah (BUMN) maupun milik swasta, salah satunya yaitu PT. Pahala Express Delivery (Pahala Express), yang menyediakan jasa pengiriman barang. Menurut website dari Pahala Express telah beroperasi sejak tahun 2008 yang memiliki kantor pusat di Bekasi, Jawa Barat dan telah mempunyai cabang pada kota-kota di Indonesia, yang mana salah satunya yaitu di Denpasar.

Pahala Express menyediakan pilihan layanan kiriman dalam negeri dan luar negeri. Untuk pengiriman barang di seluruh wilayah Bali seperti Singaraja ke Denpasar dapat melalui jalur darat dengan layanan Express. Waktu yang diperlukan untuk barang yang dikirim tiba pada tujuan yaitu maksimal dalam 2 hari sejak barang diserahkan ke Pahala Express. Penghitungan biaya yang dikenakan sesuai dengan berat/volume barang yaitu per $1 \mathrm{~kg}$ dan berbedabeda pada setiap tujuan. 
Terbentuknya suatu hubungan antara pengguna jasa dengan perusahaan jasa pengiriman barang adalah melalui suatu perjanjian pengangkutan pada dasarnya merupakan suatu perjanjian biasa, yaitu tunduk pada ketentuan yang terdapat dalam buku ke III KUHPerdata tentang perikatan, selama tidak ada pengaturan dalam perundang-undangan di bidang pengangkutan. ${ }^{2}$ Perjanjian pengangkutan ialah suatu perjanjian dimana satu pihak menyanggupi untuk dengan aman membawa orang atau barang dari satu ke lain tempat, sedangkan pihak yang lainnya menyanggupi akan membayar ongkosnya. ${ }^{3}$

Selama proses pengiriman barang dilakukan oleh perusahaan jasa pengiriman barang, wajib menanggung kerugian pengguna jasa karena kesalahan/kelalaian dalam melaksanakan pengiriman barang. Pengaturan mengenai kewajiban, hak dan tanggung jawab pengangkut, terdapat dalam Bagian Kesebelas, mulai dari Pasal 186 sampai Pasal 197 Undang-Undang No.22 Tahun 2009 tentang Lalu Lintas dan Angkutan Jalan. Selain itu terdapat juga pengaturan mengenai perlindungan terhadap pengguna jasa dan/atau barang yaitu Undang-Undang No.8 Tahun 1999 tentang Perlindungan Konsumen (selanjutnya disebut UUPK) terdapat hak dankewajiban pengguna jasa sebagai konsumen dengan pelaku usaha dalam melakukan kegiatan usahanya.

Diaturnya dalam peraturan perundang-undangan tersebut, maka perusahaan jasa pengiriman barang harus dapat menjamin kualitas keamanan dan keselamatan pelayanannya. Namun demikian masih saja terdapat masalah yang timbul dalam melaksanakan pengiriman barang. Masalah-masalah ini seperti

2 Siti Nurbaiti, 2009, Hukum Pengangkutan Darat (Jalan dan Kereta Api), Universitas Trisakti, Jakarta, h. 13. 69.

3 Subekti R., 2014, Aneka Perjanjian, PT. Citra Aditya Bakti, Bandung, h. 
terjadinya keterlambatan, kerusakan, maupun kehilangan barang yang dikirim. Masalah ini mengakibatkan pihak pengguna jasa menderita kerugian karena barang miliknya tidak ditangani dengan baik sesuai kesepakatan dan biaya yang telah dibayarkan.

Pengguna jasa kebanyakan hanya menyampaikan keluhanya melalui tulisan-tulisan di internet/media sosial yang jarang ditanggapi oleh pengangkut. Pada kenyataannya penjelasan mengenai resiko-resiko yang dapat terjadi selama melaksanakan pengiriman barang jarang diberitahukan. Salah satu faktor utama yang menjadi kelemahan konsumen adalah tingkat kesadaran akan haknya memang masih sangat rendah, hal ini terutama disebabkan oleh kurangnya kesadaran dari pihak konseumen itu sendiri. ${ }^{4} \mathrm{Hal}$ inilah yang harus diperhatikan agar masyarakat yang sudah percaya menggunakan jasa pengiriman barang dapat terlindungi dari kerugian-kerugian tersebut.

\subsection{Tujuan Penulisan}

Tujuan dari penelitian ini adalah untuk mengetahui secara mendalam tindakan preventif PT. Pahala Express Delivery Denpasar untuk menghindari terjadinya kerugian terhadap pengguna jasa dan tanggung jawab PT. Pahala Express Delivery Denpasar terhadap kerugian yang diderita oleh pengguna jasa.

\section{ISI MAKALAH}

\subsection{Metode Penelitian}

Penelitian hukum pada dasarnya merupakan suatu kegiatan ilmiah yang didasarkan pada metode, sistematika dan pemikiran

4 A.A. Gde Agung Brahmanta, Ibrahim R, I Made Sarjana, 2016, "Perlindungan Hukum Bagi Konsumen Dalam Perjanjian Baku Jual Beli Perumahan Dengan Pihak Pengembang Di Bali”, Acta Comitas, Vol. 1 No. 2, Oktober 2016, h. 208,https://ojs.unud.ac.id/index.php/ActaComitas/article/view/24953 diakses tanggal 13 Februari 2019. 
tertentu yang bertujuan mempelajari satu atau beberapa gejala hukum dan menganalisisnya untuk kemudian memecahkan masalah dalam gejala bersangkutan. ${ }^{5}$ Jenis penelitian dalam jurnal ini memakai penelitian hukum empiris, mengkaji mengenai implementasi ketentuan peraturan perundang-undang dari suatu peristiwa hukum di masyarakat, yaitu mendekatkan masalah dari kenyataan-kenyataan yang terjadi dalam perlindungan hukum terhadap pengguna jasa pengiriman barang pada PT. Pahala Express Delivery Denpasar dan dihubungkan pada ketentuan Undang-Undang yang masih berlaku.

\subsection{Hasil dan Analisis}

\subsubsection{Tindakan Preventif Yang Diberikan PT. Pahala Express Delivery Denpasar Kepada Pengguna Jasa Agar Tidak Terjadi Kerugian}

Pengangkutan sudah menjadi suatu kebutuhan bagi setiap masyarakat dalam kegiatan sehari-hari. Kegiatan mengirim barang merupakan suatu hal yang mudah dilakukan pada zaman modern saat ini karena dari segi alat angkut, jalan serta lalu lintas sudah sangat baik dan penyedia layanan pengiriman barang sudah terbilang banyak tersedia di Indonesia. Masalah pada masa kini adalah cara memajukan transportasi yang dapat menghasilkan jasa produksi angkutan yang baik murah dan dapat memenuhi kebutuhan masyarakat. 6

Selama melaksanakan pengangkutan harus memperhatikan faktor keamanan dan keselamatan barang. Perusahaan jasa pengiriman barang perlu melakukan tindakan preventif atau

5 Bambang Sunggono, 2016, Metodelogi Penelitian Hukum, Rajawali Pers, Jakarta, h. 38.

6 Soegijatna Tjakranegara, 1995, Hukum Pengangkutan Barang Dan Penumpang, Rineka Cipta, Jakarta, h. 2. 
pencegahan atas setiap barang yang akan dikirim, supaya kemudian tidak timbul kerugian-kerugian yang dapat diderita pengguna jasa. Tindakan preventif merupakan segala upaya untuk dapat mencegah suatu kejadian atau peristiwa yang mengakibatkan terjadinya kerugian.

Tanggung jawab pengangkut wajib untuk diasuransikan sesuai dengan Pasal 189 UU No.22 Tahun 2009. Asuransi merupakan perjanjian antara tertanggung dengan penanggung dalam bentuk tertulis yaitu polis asuransi, pihak tertanggung bersedia membayar premi, pihak penanggung memberi ganti rugi atas resiko kerusakan, kehilangan atau tidak dapat menerima laba yang diinginkan yang mungkin timbul atas kejadian yang belum pasti terjadi atau kerugian yang mungkin timbul dalam melaksanakan pengangkutan.

Dengan adanya asuransi apabila terjadi resiko kerusakan atau kehilangan pada barang yang diangkut maka perusahaan pengiriman barang akan mengalihkan resiko tersebut kepada pihak jasa asuransi untuk mengganti kerugian dari pengguna jasa pengiriman barang. Dalam Prosedur Standar Pengiriman Pahala Express telah mengatur mengenai asuransi dalam poin 4 e yang menyatakan, untuk barang yang nilainya tinggi/mahal wajib diasuransikan dan premi asuransi dibayar pengirim, yang artinya tidak mengasuransikan seluruh barang yang dikirim melainkan hanya mewajibkan asuransi untuk barang yang nilainya tinggi/mahal dan pembayaran preminya ditanggung oleh pengirim barang sebesar 0,20\% dari nilai barang yang dikirim.

Untuk mencegah terjadinya kerugian pada pengguna jasa, Pahala Express telah melakukan beberapa tindakan yang perlu dilakukan sebelum melaksanakan pengiriman barang yang merupakan suatu standar. Menurut penjelasan Ibu Sri Nur Aini 
Customer Service di PT. Pahala Express Delivery Denpasar bahwa tindakan untuk mencegah kerugian yaitu:

1. Memeriksa barang dengan melihat langsung kondisinya dan meminta keterangan terkait barang yang akan di kirim.

2. Mengasuransikan barang yang nilainya mahal.

3. Menyarankan untuk dibungkus (packing) oleh kantor gudang Pahala Express dengan menggunakan kayu, plastik gelembung/ bubble wrap, dan karung.

4. Apabila di bungkus sendiri maka pengirim barang wajib memberitahukan dengan benar terkait kondisi barang termasuk nilai barang.

5. Mencatat semua keterangan mengenai pengirim, tujuan penerima dan keterangan barang ke dalam surat resi pengiriman (dokumen pengangkutan).

6. Memberikan surat resi, setiap surat resi pengiriman terdapat nomor yang fungsinya untuk melacak keberadaan barang selama proses pengiriman yaitu mulai dari barang diterima sampai tiba di tujuan yang dapat diakses melalui website resmi Pahala Express, resi ini juga menjadi nota/bukti pembayaran biaya pengiriman.

7. Menyimpan barang dengan baik di gudang Pahala Express untuk persiapan pengiriman.

Apabila telah menandatangani surat resi maka dianggap telah menyetujui Prosedur Standar Pengiriman yang sudah dibuat oleh Pahala Express dan tercantum dalam surat resi pengiriman sebagai ketentuan dalam melaksanakan pengiriman barang. Dengan demikian Pahala Express sudah membuat surat muatan barang dan perjanjian pengangkutan sesuai dengan Pasal 168 UU No.22 Tahun 2009. Surat muatan barang ini memiliki fungsi untuk menjelaskan semua keterangan terkait barang yaitu jenis serta 
jumlah barang, asal dan tujuan pengiriman, sedangkan dengan adanya perjanjian akan lebih mengikat hak dan kewajiban agar dapat dilaksanakan dengan baik. Perjanjian merupakan dimana dua orang yang saling berjanjian untuk melakukan sesuatu dan mereka bersama-sama mengadakan kesepakatan. ${ }^{7}$

Dalam pemberian tindakan untuk mencegah terjadi kerugian pada barang yang akan dikirim oleh Pahala Express sudah dilakukan atau diberikan sehingga dapat memberikan kepercayaan kepada pengguna jasa bahwa barang miliknya akan di tangani dengan baik sampai tiba pada tujuan.

\subsubsection{Tanggung Jawab PT. Pahala Express Delivery Denpasar Terhadap Kerugian Yang Diderita Oleh Pengguna Jasa}

Selama melaksanakan pengangkutan pada dasarnya telah menjadi tanggung jawab pengangkut atas keselamatan dan keamanan baik penumpang maupun barang yang diangkutnya. Hukum pengangkutan terdapat tiga prinsip tanggung jawab yaitu, tanggung jawab karena kesalahan, tanggung jawab praduga bersalah, dan tanggung jawab mutlak.

Berdasarkan dari ketiga prinsip tanggung jawab tersebut diatas Pahala Express Delivery Denpasar mencerminkan prinsip tanggung jawab praduga bersalah karena untuk mengetahui kesalahan ada pada Pahala Express Delivery Denpasar atau tidak maka, Pahala Express Delivery Denpasar akan saling mengkoordinasikan antara cabang/agen asal kiriman dengan cabang penerima di tempat tujuan untuk cek kembali barang dengan surat resi yang tercatat mengenai keterangan dan

7 Anak Agung Adi Lestari, 2016, "Perjanjian Baku Dalam Jual Beli Kredit Sepeda Motor Ditinjau Dari Undang-Undang Nomor 8 Tahun 1999”, Jurnal Magister Hukum Udayana, Vol. 5 No. 2, Juli 2016, h. 338, https://ojs.unud.ac.id/index.php/jmhu/article/view/22445 diakses tanggal 13 Februari 2019. 
kelengkapan barang tersebut untuk membuktikan terjadinya kesalahan atau tidak.

Pengangkut melaksanakan pengangkutan barang dengan aman dan selamat hingga ke tujuan, jika terjadi kerusakan maupun kehilangan atas kesalaha/kelalaiannya terhadap barang-barang yang diangkut, pengangkut wajib untuk memberikan ganti kerugian kepada pemilik atau pengirim barang. Pengangkut wajib membayar ganti kerugian atas biaya, kerugian yang diderita, dan bunga yang layak diterima apabila ia tidak dapat menyerahkan atau tidak merawat sepatutnya untuk menyelamatkan barang muatan (Pasal 1236 KUHPdt). ${ }^{8}$

Pengangkut telah diwajibkan untuk bertanggung jawab atas terjadinya kerugian terhadap pengguna jasa yang terdapat pada Pasal 188 UU No.22 Tahun 2009. Selanjutnya pada Pasal 193 mengatur tanggung jawab pengangkut lebih rinci lagi terkait kerugian pengirim barang yang berakibat musnahnya barang, hilangnya barang atau rusaknya barang sedangkan, untuk penghitungan kerugian yang harus diganti sesuai dengan yang nyata-nyata dialami oleh pengirim barang.

Selain itu dalam Pasal 19 UUPK juga menyebutkan tanggung jawab pelaku usaha yaitu memberikan ganti kerugian kepada konsumen dalam hal ini penguna jasa dan ganti rugi dapat berbentuk pengembalian uang, penggantian barang atau jasa sejenis atau nilai yang setara atau pemberian santunan. Pelaku usaha dalam hukum perlindungan konsumen harus dapat di mintakan pertanggung jawaban, yaitu jika perbuatannya telah

${ }^{8}$ Abdulkadir Muhammad, 2013, Hukum Pengangkutan Niaga, PT. Citra Aditya Bakti, Bandung, h. 42. 
melanggar hak-hak dan kepentingan konsumen, menimbulkan kerugian. ${ }^{9}$

Pahala Express Delivery Denpasar bersedia mengganti rugi kehilangan barang atau kerusakan barang disebabkan karena kelalaian dari Pahala Express dan tidak bertanggung jawab atas kerugian yang timbul karena kesalahan pemilik barang atau terjadi bencana alam (force majeur). Sebelum mendapatkan ganti rugi pengguna jasa wajib memenuhi tata cara klaim pada poin 5 Prosedur Standar Pengiriman Pahala Express yaitu:

a. Pengaduan keluhan atas barang kiriman tidak dapat dilayani apabila lebih dari $1 \times 24$ jam sesudah barang diterima.

b. Pengajuan klaim hanya dapat diajukan jika poin 5 a terpenuhi. Pengajuan ditujukan ke kantor Pahala Express secara tertulis dan sudah harus diterima di kantor Pahala Express dalam batas waktu 15 hari kerja terhitung dari tanggal dokumen atau barang tersebut diterima di tujuan.

c. Pengajuan klaim dilakukan dengan melampirkan dokumendokumen pendukung seperti: bukti nota asli dari Pahala Express, foto copy KTP, surat permohonan penutupan asuransi (bila diasuransikan).

Dengan melengkapi syarat-syarat diatas pengguna jasa berhak menerima ganti rugi.

Menurut penjelasan Ibu Sri Nur Aini Customer Service di PT. Pahala Express Delivery Denpasar bahwa penggantian kerugian atas kehilangan maupun kerusakan untuk barang tidak

${ }^{9}$ Ni Komang Ayu Nira Relies Rianti, 2017, "Tanggung Jawab Pelaku Usaha Terhadap Konsumen Dalam Hal Terjadinya Hortweighting Ditinjau Dari UndangUndang RI No 8 Tahun 1999 Tentang Perlindungan Konsumen", Jurnal Magister Hukum Udayana, Vol. 6 No. 4, Desember 2017, h. 531, https://ojs.unud.ac.id/index.php/jmhu/article/view/37177 diakses tanggal 13 Februari 2019. 
diasuransikan yaitu sepuluh kali biaya pengiriman dengan nilai maksimal Rp. 750.000 per kiriman. Untuk menentukan nilai ganti rugi ditentukan meninjau dari nilai barang yang saat itu tercatat di Pahala Express, tanpa menghubungkanya dengan nilai komersil (nilai jual di pasaran) dan melihat dari kerusakan atau kehilangan terhadap barang tersebut. Apabila barang kiriman diasuransikan maka akan ditanggung dengan jasa asuransi rekanan Pahala Express. Nilai tanggungan asuransi yang diberikan ditentukan sesuai dengan keterangan nilai barang yang dicatat dan sesuai dengan kerusakan atau kehilangan yang dialami. Kalau masalah ganti rugi biasanya hanya sampai pemberian ganti rugi saja sudah selesai tidak sampai proses hukum.

Berdasarkan hasil wawancara tersebut Pahala Express Delivery Denpasar sudah memberikan ganti rugi sebagai bentuk dari tanggung jawabnya terhadap kerugian yang diderita pengguna jasa, akan tetapi apabila barang yang tidak diasuransikan nilai kerusakan atau kehilangan barang yang hingga melebihi Rp.750.000 maka tidak akan dapat di tanggung secara penuh. Sehingga pengguna jasa tidak mendapatkan ganti rugi yang nyatanyata dialami maka belum dapat memenuhi ketentuan Pasal 193 ayat (2) UU No.22 Tahun 2009.

Mengenai keterlambatan barang sampai pada tujuan menurut Ibu Sri Nur Aini Customer Service di PT. Pahala Express Delivery Denpasar menjelaskan bahwa keterlambatan sampainya barang kiriman layanan Express tidak diberikan ganti rugi keterlambatan karena estimasi atau perkiraan waktu yang sudah terbilang cukup, jadi kecil kemungkinan terjadinya keterlambatan.

Keterlambatan merupakan tidak sesuai dengan yang diperjanjikan karena telah melewati batas waktu yang telah diperjanjikan. Dalam isi Pasal 1243 KUHPerdata telah mengatur 
mengenai wanprestasi, Melihat dari pasal tersebut apabila terjadi keterlambatan yang disebabkan oleh kelalaian dari pengangkut maka, wajib untuk memberikan ganti rugi kepada pengirim barang atas keterlambatan sampainya barang tiba di tujuan. Pengangkut dapat menyatakan tidak bertanggung jawab jika keterlambatan yang terjadi karena force majeur/keadaan memaksa sesuai dengan Pasal 92 KUHD.

\section{PENUTUP}

\subsection{Kesimpulan}

1. Tindakan preventif yang diberikan oleh PT. Pahala Express Delivery Denpasar untuk mencegah terjadinya kerugian pengguna jasa sudah dilakukan dengan baik yaitu dengan memeriksa dan meminta keterangan barang, mengasuransikan barang mahal, menyarankan dibungkus menggunakan kayu, plastik gelembung dan karung. Mencatat keterangan barang, pengirim dan tujuan penerima ke dalam surat resi. Memberikan surat resi berisikan nomor berfungsi untuk melacak keberadaan barang dan sebagai nota/bukti pembayaran. Semua ini telah diatur dalam Prosedur Standar Pengiriman Pahala Express.

2. Tanggung jawab PT. Pahala Express Delivery Denpasar terhadap kerugian pengguna jasa belum sepenuhnya sesuai dengan Peraturan Perundang-undangan karena ganti rugi yang diberikan kepada pengguna jasa yang mengalami kerusakan atau kehilangan barang untuk yang tidak diasuransikan tidak dapat ditanggung secara penuh apabila melebihi 10x (sepuluh) biaya pengiriman dengan jumlah maksimal tidak melebihi Rp.750.000. Mengenai keterlambatan layanan Express tidak diberikan ganti rugi keterlambatan. 


\subsection{Saran}

1. Hendaknya perusahaan pengiriman barang sebagai pengangkut dalam hal ini Pahala Express Delivery Denpasar dalam melaksanakan pengiriman barang mengasuransikan seluruh barang yang diangkutnya supaya apabila terjadi kerusakan maupun kehilangan barang dapat diberikan ganti rugi secara penuh tidak dibatasi.

2. Sebaiknya dalam hal terjadi keterlambatan tiba pada tujuan layanan Express diberikan potongan biaya sebagai bentuk dari ganti rugi.

\section{DAFTAR PUSTAKA}

\section{BUKU}

Abdulkadir Muhammad, 2013, Hukum Pengangkutan Niaga, PT. Citra Aditya Bakti, Bandung.

Bambang Sunggono, 2016, Metodelogi Penelitian Hukum, Rajawali Pers, Jakarta.

H.M.N. Purwosutjipto, 2003, Pengertian Pokok Hukum Dagang Indonesia III Hukum Pengangkutan, Djambatan, Jakarta.

R. Subekti, 2014, Aneka Perjanjian, PT. Citra Aditya Bakti, Bandung.

Siti Nurbaiti, 2009, Hukum Pengangkutan Darat (Jalan dan Kereta Api), Universitas Trisakti, Jakarta.

Soegijatna Tjakranegara, 1995, Hukum Pengangkutan Barang Dan Penumpang, Rineka Cipta, Jakarta.

\section{Jurnal Ilmiah}

A.A. Gde Agung Brahmanta, Ibrahim R, I Made Sarjana, 2016, "Perlindungan Hukum Bagi Konsumen Dalam Perjanjian Baku Jual Beli Perumahan Dengan Pihak Pengembang Di Bali”, Acta Comitas, Vol. 1 No. 2, Oktober 2016, h. 208, 
https://ojs.unud.ac.id/index.php/ActaComitas/article/view/ $\underline{24953}$ diakses tanggal 13 Februari 2019.

Anak Agung Adi Lestari, 2016, "Perjanjian Baku Dalam Jual Beli Kredit Sepeda Motor Ditinjau Dari Undang-Undang Nomor 8 Tahun 1999", Jurnal Magister Hukum Udayana, Vol. 5 No. 2, Juli 2016, h. 338, https://ojs.unud.ac.id/index.php/jmhu/article/view/22445 diakses tanggal 13 Februari 2019.

Ni Komang Ayu Nira Relies Rianti, 2017, "Tanggung Jawab Pelaku Usaha Terhadap Konsumen Dalam Hal Terjadinya Hortweighting Ditinjau Dari Undang-Undang RI No 8 Tahun 1999 Tentang Perlindungan Konsumen", Jurnal Magister Hukum Udayana, Vol. 6 No. 4, Desember 2017, h. 531, https://ojs.unud.ac.id/index.php/jmhu/article/view/37177 diakses tanggal 13 Februari 2019.

\section{Peraturan Perundang-Undangan}

Kitab Undang-Undang Hukum Perdata, Burgerlijk Wetboek, Tahun 2008, diterjemahkan oleh R. Subekti dan R. Tjitrosudibio, PT. Pradnya Paramita, Jakarta.

Kitab Undang-Undang Hukum Dagang, Wetboek van Koophandel, Tahun 2010, diterjemahkan oleh Tim Redaksi Pustaka Yustisia, Pustaka Yustisia, Jakarta.

Undang-Undang Nomor 8 Tahun 1999 tentang Perlindungan Konsumen, Lembaran Negara Republik Indonesia Tahun 1999 Nomor 42, Tambahan Lembaran Negara Republik Indonesia Nomor 3821.

Undang-Undang Nomor 22 Tahun 2009 tentang Lalu Lintas dan Angkutan Jalan, Lembaran Negara Republik Indonesia Tahun 2009 Nomor 96, Tambahan Lembaran Negara Republik Indonesia Nomor 5025. 